\title{
The Impact of Program-Wide Discussion Board Grading Rubrics on Students and Faculty Satisfaction
}

\author{
Brinda McKinney \\ Arkansas State University
}

\begin{abstract}
In addition to learning more about a topic, online discussion activities may be used to develop skills in reflective practice, critical evaluation, and leadership. Faculty members often spend a great amount of time and energy developing discussion assignments that will improve these skills and align with course learning outcomes. Students may feel the online discussion forum assignments lack clarity and are uncertain about how to proceed. Confusion about the assignment occurs when the instructor's expectations about the discussion activity and the students' understanding about the assignment do not align. This article will review a collaborative process used to align instructor expectations and student understanding in order to evaluate online discussion board assignments in a fair and objective manner.
\end{abstract}

Keywords: Online, discussion board, assignments, students, instructors, grading rubric, expectations, RN-BSN program, faculty

McKinney, B.K. (2018). The impact of program-wide discussion board grading rubrics on students and faculty satisfaction. Online Learning, 22(2), 289-299. doi:10.24059/olj.v22i2.1386

\section{The Impact of Program-Wide Discussion Board Grading Rubric on Student and Faculty Satisfaction}

Online discussion activities are routinely used to engage learners in course content, based on the belief that this type of engagement helps online learners to grasp concepts, improve understanding, and develop skills in reflective practice, critical evaluation, and leadership. To accomplish these goals, discussion assignments must align with course learning outcomes and engage students. The development of such activities can be daunting as educators attempt to facilitate active learning within a group threaded discussion assignment. Once the discussion activity is designed, instructors may believe the most difficult part is behind them. However, for both novice and experienced instructor, facilitation and evaluation of discussion activities can be more overwhelming and time consuming than developing the assignment itself. Faculty members may be disheartened to find that students do not engage in the manner or at the level they had anticipated. 
On the other hand, students may feel that the discussion assignment lacks clarity and therefore experience confusion about how to proceed. Perceived ambiguity about the assignment is likely to affect students' ability or willingness to fully understand the value of the threaded discussion as a learning forum.

Confusion occurs when the instructor's expectations about the discussion activities and students' understanding about the assignment do not align (Brokensha \& Greyling, 2015). Thus, educating students about exactly what is expected in discussion board assignments is vital to enabling them to engage at the expected level. Likewise, providing specific expectations for the discussion board assignments prompts the instructor to provide growth-producing feedback to students.

The aim of this project was to collaboratively develop an online RN-BSN program-wide discussion activity grading rubric that clearly outlined expectations for student participants and provide clear and consistent guidelines for faculty assessment of discussion assignment activity, as well as to provide a means of specific, meaningful feedback to students.

\section{Review of Related Literature}

Online discussion activities are often used to develop skills in reflective practice, critical evaluation, and leadership, as well as to increase knowledge about a given topic (Gillespie, Pritchard, Bankston, Burno, \& Glazer, 2016; Nielsen, Lasater, \& Stock, 2016; Smith, 2015). Historically, discussion board activities have worked well for concept-focused objectives and the development of problem-solving skills (Schnetter, O'Neal, Lacy, Jones, Bakrim, \& Allen, 2014). The use of threaded discussion activities in an online environment can best facilitate active learning in students who are engaged (Jain \& Jain, 2015). Faculty members often spend a significant amount of time and energy developing discussion post assignments that align with course learning outcomes (Bedford, 2014) only to discover that the threaded discussion assignment does not engage students in the way the instructor envisioned. Regardless of teaching experience, evaluating online discussion assignments can seem overwhelming and laborious (Curry \& Cook, 2014; Gillespie, Pritchard, Bankston, Burno, \& Glazer, 2016). The development of discussion activities may seem challenging as educators attempt to facilitate learning within a threaded discussion assignment.

Unfortunately, the development of the assignment is only the beginning. After the tedious work of developing the threaded discussion assignment follows the task of evaluating how well students engaged in the assignment. Complex discussions can be difficult to grade without a wellconstructed rubric (Phillippi, Schorn, \& Moore-Davis, 2015). Instructors may be disheartened after designing a well-thought-out discussion board activity only to find students do not engage in the manner or at the level the instructor had anticipated.

On the other hand, students may feel the online discussion assignment lacks clarity and be at a loss on how to proceed. This may be due in part to the students' perception of online education activity (Frimming \& Bordelon, 2016). Students may not fully understand the value of the threaded discussion as a learning forum (Acolatse, 2016) and view it as merely busy work. Additionally, students often describe ambiguity in regards to various tasks embedded in the assignment, including purpose, depth, and recipient of their writing (Carnegie Mellon University, 2015). O'Brien, Marken, \& Petrey (2016) found some key elements for student success with this type of 
writing assignment. They claim that "students will work to achieve the expected standard for scholarship" if they have "opportunities for repetition and practice" with specific "instructional strategies and explicit instructor feedback" (O'Brien, Marken, \& Petrey, 2016, p. 12).

If the discussion forum lacks clarity for either the students or the instructor, problems ensue (Nandi, Hamilton, \& Harland, 2012). Without clear directions about the level and type of engagement expected, discussion board forums may not lead to a better understanding of the subject matter (Oh \& Steefel, 2016).

Instructor feedback plays a significant role in the quality and values of online discussion forums (Delahunty, Jones, \& Verenikina, 2014). Since educators must provide accurate student evaluations, a grading rubric that consistently assesses student performance and provides meaningful feedback is vital (Shipman, Roa, Hooten, \& Wang, 2012). Such grading tools have been shown to reduce faculty workload and increase overall student scores (Bishop, Grubesic, \& Parrish, 2015). Thus, instructing students on exactly what is expected in online discussion board assignments is vital to enabling the student to deliver the content engagement that is sought while meeting all of the requirements of the assignment.

It is noteworthy that when learning outcomes match clearly outlined expectations, student satisfaction is increased (Schnetter et al., 2014). Additionally, the use of assessment rubrics significantly encouraged student participation and achievement (Wuttikietpaiboon, 2012). Specifically outlining the expectations for the online discussion board assignments can be useful in prompting the instructor to provide growth-producing feedback to students participating in the activity. Both student and faculty input regarding the rubric will significantly contribute to the evolvement of the tool (Wright, Scherb, \& Forsyth, 2011).

The aim of this project was to collaboratively develop an online RN-BSN program-wide discussion board activity grading rubric that clearly outlines expectations for student participants and provides clear and consistent guidelines for faculty's assessment of discussion forum activity, as well as specific, meaningful feedback to students.

\section{Methods}

To begin this process, online RN-BSN faculty members met to discuss the need for a program-wide discussion board grading rubric. To better understand the opportunity for improvement, faculty members reviewed student complaints about the wide variety of expectations among instructors within the RN-BSN program. Such variety, students claimed, made comprehension and completion of discussion board expectations very difficult. Students also noted that they often did not understand what they did wrong, making it difficult to improve on future discussion board assignments. With this in mind, faculty members decided that the creation of a program-wide online grading rubric for discussion board activities might address student concerns.

Faculty members first identified the similarities in their discussion board activity assignments. Although applied in slightly different ways, each faculty member had specific expectations for the initial posting, follow-up postings, incorporation of current literature, frequency of postings, and mechanics. After concurring on general categories of (1) Content, (2) Frequency of Postings, (3) Initial Assignment Posting Content, (4) Follow-up Postings Content, (5) References and Support, and (6) Clarity and Mechanics, each category was evaluatively defined. 
Faculty members collaborated to determine evaluation criteria for each category. Processes and their rationale related to discussion board activities were shared and considered by the group. Regarding initial postings and frequency of postings, faculty members agreed that initial postings should be required by midnight on Wednesday of each week of a discussion board activity assignment. This would allow for student interaction with follow-up postings during the remainder of the week. Faculty members then discussed the frequency of follow-up postings. After discussion and literature consultation, faculty members determined that a minimum of two (2) follow up postings on at least two (2) different days of the week was sufficient. Over the next six weeks, faculty members met regularly to defined the grading rubric criteria for each of the following areas: (1) Content, (2) Frequency of Postings, (3) Initial Assignment Posting Content, (4) Follow-up Postings Content, (5) References and Support, and (6) Clarity and Mechanics.

For the next step, faculty considered the grade weight of discussion board activities. After significant discussion about the variety of courses in the program, it was determined that a basic point allowance should be used for every discussion activity in the RN-BSN program. It was noted that discussion board activities were more meaningful in some courses than in others. Therefore, each instructor, with the assistance of the program chairperson, would be responsible for determining what percentage of the final course grade would be attributed to discussion board assignments. Additionally, faculty members would consider course content to determine how many discussion board activity assignments were appropriate for their courses.

With the knowledge of the total point allocation for a discussion board assignment, faculty members made a grid with all six criteria and included the points for each criterion for Excellent performance. Fewer points were earned for the categories Proficient, Marginal, and Unacceptable. Faculty members worked for several more weeks to describe the specific criteria of each level of performance under each category. Although this was a great deal of work, faculty members viewed the process with a great sense of accomplishment. The final grading rubric (see Table 1) offered an objective and content-valid framework for the evaluation of online discussion board activity that Wright, Scherb, and Forsyth, (2011) claimed would be valuable to both the instructor and to the student. 


\begin{tabular}{|c|c|c|c|c|}
\hline & Excellent $3(16.67 \%)$ points & $\begin{array}{l}\text { Proficient } 2(11.11 \%) \\
\text { points }\end{array}$ & $\begin{array}{l}\text { Marginal } 1 \\
(5.56 \%) \text { points }\end{array}$ & $\begin{array}{l}\text { Unacceptable } 0 \\
(0 \%) \text { points }\end{array}$ \\
\hline Content & $\begin{array}{l}\text { Factually correct, reflective, and } \\
\text { substantive contribution which } \\
\text { advances discussion. } \\
\text { The posting content must be reflective } \\
\text { and substantive-not just facts. Note } \\
\text { that you will not be able to do this } \\
\text { with a few sentences. You will } \\
\text { typically need a minimum of } 1 / 2 \text { page } \\
\text { (or around } 200 \text { words) to develop a } \\
\text { thought reflectively and substantively. }\end{array}$ & $\begin{array}{l}\text { Information is } \\
\text { factually correct but } \\
\text { lacks full development } \\
\text { of concept or thought. }\end{array}$ & $\begin{array}{l}\text { Repeats } \\
\text { resources but } \\
\text { does not add } \\
\text { substantive } \\
\text { information to } \\
\text { the discussion. }\end{array}$ & $\begin{array}{l}\text { Information is off } \\
\text { topic, incorrect, or } \\
\text { irrelevant to the } \\
\text { discussion. }\end{array}$ \\
\hline Frequency & $\begin{array}{l}\text { Responds to the discussion question } \\
\text { by midnight on Wednesday and posts } \\
\text { at least two responses to two different } \\
\text { peers on two other days during the } \\
\text { week. (Student participates on three } \\
\text { or more days during the week.) } \\
\text { Note: You are required to post on } \\
\text { three different days of the week to } \\
\text { earn all the frequency points. }\end{array}$ & $\begin{array}{l}\text { Responds to the } \\
\text { discussion question by } \\
\text { midnight on } \\
\text { Wednesday and posts } \\
\text { one response to a peer. } \\
\text { (Student must } \\
\text { participate in the } \\
\text { discussion at least } 2 \\
\text { different days.) }\end{array}$ & $\begin{array}{l}\text { Responds to the } \\
\text { discussion } \\
\text { question by } \\
\text { Friday and/or } \\
\text { only participates } \\
\text { on one day of } \\
\text { the week. }\end{array}$ & $\begin{array}{l}\text { No evidence of } \\
\text { participation or } \\
\text { participates after } \\
\text { Friday only. }\end{array}$ \\
\hline $\begin{array}{l}\text { Initial } \\
\text { Assignment } \\
\text { Posting }\end{array}$ & $\begin{array}{l}\text { Posts well-developed assignment that } \\
\text { fully addresses and develops all } \\
\text { aspects of the discussion. } \\
\text { This section looks specifically at all } \\
\text { parts of the discussion assignment. }\end{array}$ & $\begin{array}{l}\text { Posts an adequately } \\
\text { developed assignment } \\
\text { that addresses all } \\
\text { aspects of the } \\
\text { assignment; lacks full } \\
\text { development of some } \\
\text { concepts/topics. }\end{array}$ & $\begin{array}{l}\text { Posts loosely } \\
\text { developed } \\
\text { assignment with } \\
\text { superficial } \\
\text { thought and } \\
\text { preparation; } \\
\text { doesn't address } \\
\text { all aspects of } \\
\text { discussion. }\end{array}$ & $\begin{array}{l}\text { No response to } \\
\text { discussion } \\
\text { question. }\end{array}$ \\
\hline $\begin{array}{l}\text { Follow-up } \\
\text { Postings }\end{array}$ & $\begin{array}{l}\text { Demonstrates analysis of other's } \\
\text { posts; extends meaningful discussion } \\
\text { by building on previous posts. Any } \\
\text { questions posed to peers are } \\
\text { thoughtful and relevant to discussion. } \\
\text { Includes current literature (peer- } \\
\text { reviewed journal article written within } \\
\text { the last } 5 \text { years) citation/reference. } \\
\text { Note: You may agree or disagree but } \\
\text { that does not demonstrate analysis or } \\
\text { extend meaningful discussion. Tell } \\
\text { why and add new information to } \\
\text { support your reasoning. }\end{array}$ & $\begin{array}{l}\text { Elaborates on an } \\
\text { existing posting with } \\
\text { further comment or } \\
\text { observation. May ask } \\
\text { peer question to clarify } \\
\text { and seek further input } \\
\text { from peer. Does not } \\
\text { include a current } \\
\text { literature (peer- } \\
\text { reviewed journal } \\
\text { article written within } \\
\text { the last } 5 \text { years) } \\
\text { citation/reference. }\end{array}$ & $\begin{array}{l}\text { Posts shallow } \\
\text { contribution to } \\
\text { discussion (e.g. } \\
\text { agrees or } \\
\text { disagrees but } \\
\text { doesn't } \\
\text { elaborate); does } \\
\text { not enrich the } \\
\text { discussion. }\end{array}$ & $\begin{array}{l}\text { No follow up } \\
\text { responses to peers }\end{array}$ \\
\hline
\end{tabular}


Table 1. (cont.)

Discussion Board Rubric

\begin{tabular}{|c|c|c|c|c|}
\hline $\begin{array}{l}\text { References } \\
\text { and } \\
\text { Support }\end{array}$ & $\begin{array}{l}\text { Utilizes } 2 \text { or more references to } \\
\text { current literature (peer-reviewed } \\
\text { nursing journal article written within } \\
\text { the last } 5 \text { years) in addition to the } \\
\text { assigned course readings to } \\
\text { support comments using correct } \\
\text { APA formatting. } \\
\text { Note: Reference list must match in- } \\
\text { text citations and vice versa. } \\
\text { Simply making a list of reference at } \\
\text { the bottom of the post without citing } \\
\text { them in the narrative is not using } \\
\text { current literature. }\end{array}$ & $\begin{array}{l}\text { Incorporates one } \\
\text { reference from } \\
\text { current literature in } \\
\text { addition to the } \\
\text { assigned course } \\
\text { readings or personal } \\
\text { experience, using } \\
\text { correct APA } \\
\text { formatting. }\end{array}$ & $\begin{array}{l}\text { Uses personal } \\
\text { experience or } \\
\text { reference to } \\
\text { course reading } \\
\text { but no } \\
\text { references to } \\
\text { current } \\
\text { literature. }\end{array}$ & $\begin{array}{l}\text { No references or } \\
\text { supporting } \\
\text { evidence is } \\
\text { included. }\end{array}$ \\
\hline $\begin{array}{l}\text { Clarity and } \\
\text { Mechanics }\end{array}$ & $\begin{array}{l}\text { Contributes to discussion with clear, } \\
\text { concise comments formatted in an } \\
\text { easy to read style that is free of } \\
\text { grammatical, punctuation, } \\
\text { spelling, or APA format errors. } \\
\text { Suggestion: Write your post in a } \\
\text { word document, use spell and } \\
\text { grammar check, then copy and paste } \\
\text { it into the discussion board. Do not } \\
\text { attach a file that must be opened to } \\
\text { read. }\end{array}$ & $\begin{array}{l}\text { Contributes valuable } \\
\text { information to } \\
\text { discussions with } \\
\text { minor }(1-2) \text { errors in } \\
\text { grammar, } \\
\text { punctuation, spelling, } \\
\text { or APA errors. }\end{array}$ & $\begin{array}{l}\text { Communicates } \\
\text { in a friendly } \\
\text { courteous } \\
\text { manner with } \\
\text { some (3-5) } \\
\text { errors in } \\
\text { grammar, } \\
\text { punctuation, } \\
\text { spelling, or } \\
\text { APA format. }\end{array}$ & $\begin{array}{l}\text { Posts contain } \\
\text { multiple (over 5) } \\
\text { errors in } \\
\text { grammar, } \\
\text { punctuation, } \\
\text { spelling, or APA } \\
\text { format or are } \\
\text { long, } \\
\text { unorganized, } \\
\text { and/or contains } \\
\text { rude content. } \\
\text { Inappropriate } \\
\text { comments will be } \\
\text { removed and the } \\
\text { no points for the } \\
\text { week will be } \\
\text { awarded for } \\
\text { discussion board. }\end{array}$ \\
\hline
\end{tabular}

\section{Implementation}

Once the program-wide discussion board grading rubric was completed, faculty members piloted the tool. The rubric was loaded into each of the RN-BSN online courses. Inside Blackboard LMS, the rubric was interactive, allowing instructors to simply click the performance level of the student which provided automatic narrative feedback, as well as automatic calculation of student scores. This format also allowed for additional, personalized feedback that instructor could use if so desired.

Students were given a copy of the grading rubric at the beginning of the course and encouraged to seek clarification as needed. Students were instructed to re-read the discussion board grading rubric each week prior to work on their initial discussion board posting or responding to any of their classmates' postings. The grading rubric was posted inside each week's discussion 
board assignment for ease of access. Each week, students were notified when discussion board activities were graded and told to go to their grade book, review their grading rubric comments, and notify their instructor of any questions.

\section{Evaluation}

Prior to implementation of the discussion board grading rubric, faculty members and academic assistants (AAs) were asked to anonymously disclose the average amount of time they allotted to grading discussion board activity. Since this had been a collaborative effort, faculty shared the amount of time they typically spent grading discussion board activities in each of the courses they taught. The sample included all full-time instructors who taught an online RN-BSN course, whether or not they had participated in the collaborative effort to build the discussion board grading rubric. Eight faculty members reported their average time. This provided a baseline measurement of the effect of the discussion board grading rubric on grading time for the faculty. Additionally, student comments about discussion board activity/grading were pulled from previously taught courses and categorized. Data were collected a second time after the discussion board grading rubric was used for a seven-week online course. Faculty members were again asked to anonymously disclose the average amount of time they allotted to grading discussion board activity. After the course closed and student evaluations were submitted, the student evaluation comments were pulled and categorized according to discussion board activity/grading.

\section{Results}

Prior to the implementation of the discussion board grading rubric, faculty members reported spending from 15 to 30 minutes per student for weekly discussion board activity grading and feedback which averaged 21 minutes per student. With enrollment in most classes at maximum capacity of 30 students per faculty member, this accounted for 10.5 hours of grading time per week prior to the implementation of the program-wide discussion board grading rubric.

By the end of the seven-week course term in which the rubric was implemented, faculty members reported 8.2 minutes spent per student for discussion board activity grading and feedback. In courses with maximum enrollment of 30 students, faculty members were now spending 4.1 hours ( 4 hours and 6 minutes) grading discussion activity assignments. Thus, faculty spent 12.8 fewer minutes grading each student's discussion board activity. In a course with 30 nursing students, this was a saving of 6 hours and 24 minutes per faculty member per week in weeks where a required discussion board activity occurred.

This time saving is compounded for the nursing faculty as a whole. Each seven-week interval, at least twelve online RN-BSN courses are taught. Eight of the twelve online nursing courses have an average of three discussion board activities during their seven week duration. Therefore, eight faculty members saved an average of 6 hours and 24 minutes per week, totaling 51.2 hours across all eight faculty members and 153.6 hours when the three weeks of discussion activity are totaled. As a team, the online nursing faculty in the RN-BSN program has regained approximately four weeks of full-time faculty hours over a seven-week term.

In a follow-up survey, faculty members reported a $73 \%$ increase in satisfaction with discussion board activity assignments inside their online courses as a result of decreased grading time and student complaints. Several faculty members claimed they felt they actually "provide better feedback to students" since they can click a section of the rubric to make specific comments. 
Faculty also noted they "no longer dread the weeks there is a discussion board assignment to grade." Two faculty members noted their plan to add a discussion board assignment to another week in their course.

Students also benefitted from the implementation of the program-wide discussion board grading rubric. Prior to implementation of the rubric, students frequently had many questions about discussion board assignments and their grades on these assignments. Faculty members frequently heard complaints from students regarding discussion board assignments and discussion board activity grades. Typically, more than $50 \%$ of students in a course submitted negative comments or complaints about the discussion board activity grading, either to the course instructor or to the program director. The most frequent categories of student complaints about discussion board activity and grading on the course evaluations were "I don't know why the instructor counted points off of my grade," (21\%); "This instructor is much stricter on APA format than my last one was," (18\%); "This instructor does not grade like my previous nursing course instructor," (17\%); "The instructor counts off for spelling/grammar," (12\%); "My last instructor gave me until Friday to upload my discussion board posting," (11\%); "I don't know what the instructor wants, " (15\%); and other miscellaneous complaints accounted for the remaining six percent.

After the implementation of the program-wide discussion board rubric, student complaints during the seven-week course steadily dwindled by $67 \%$. Students were directed back to the grading rubric and to the comments on the grading rubric for almost all inquiries. Over 50\% students who received specific feedback from the grading rubric indicated that it was very helpful. On the course evaluation under comments about the course instructor, some students noted that "my instructor provided very specific feedback on the discussion activity that helped me in other weeks." At the end of the first term that utilized the new grading rubric, course evaluations had improved, with $25 \%$ fewer negative comments about discussion board activity and grading. At the end of the next seven-week term, student course evaluation comments were again considered. Negative comments about discussion board activity and grading had dropped by another $30 \%$.

\section{Discussion}

The intent of online discussion forums is student learning at some level. It is not desirable for the discussion board activity to be confusing or vague to students. Specific and detailed feedback from instructors may increase student learning and decrease student frustration within online discussion forums. However, this level of feedback is time consuming and instructors may repeat comments to multiple students. Programs that develop a standardized online discussion board grading rubric may benefit both instructors and students. Although the initial time investment to create a program-wide grading rubric is substantial, there may be a significant return on the investment including regained time and increased faculty satisfaction with online courses. Students who become familiar with the online grading rubric tool may have a clearer understanding of what level of engagement will be expected of them for online discussion forums. These students will then have the opportunity to match their efforts to the instructor's expectations. Such grading tools provide a means of consistency in grading between courses within an online program of study. The grading rubric may enable instructors to evaluate discussion forum work both quantitatively and qualitatively and offer an array of feedback comments, including but not limited to, content quality, evidence-based practice, frequency, and mechanics, with less time and fewer energy resources. 
This activity encourages faculty to consider how they are alike in their course assignment expectations and grading procedures, rather than their differences. Additional research is needed to determine how well this collaborative approach will work in online programs in other disciplines, as well as with other types of course evaluation. A longitudinal study would be beneficial to determine student satisfaction with regards to an entire program of study. The steps of this project are replicable in any educational setting and for programs that includes several courses within a program of study that has similar assignment types. This process can be duplicated at other schools/universities, in online program other than nursing, and with assignment types other than discussion board activities. This project was limited to one university in the mid-south. It was designed specifically for an online RN-BSN program and was designed to address student and faculty concerns about discussion board activities. It has not been used with other programs on campus. Additionally, the project did not control for any other outside variables that might affect student discussion board grades. 


\section{References}

Acolatse, T. W. (2016). Enhancing the online classroom: Transitioning from discussion to engagement. Online Journal of Distance Learning Administration, 1. Retrieved from http://oldlibrary.westga.edu/ distance/ojdla/fall193/acolatse193.html

Carnegie Mellon University (2015). Teaching Excellence \& Educational Innovation: Solve a teaching problem. Retrieved from https://www.cmu.edu/teaching/solveproblem/stratcantwrite/cantwrite-06.html

Bishop, B. W., Grubesic, T. H., \& Parrish, T. (2015). Collaborative development and assessment of student learning outcomes for LIS electives. Journal of Education for Library and Information Science, 56(4), 272-282.

Brokensha, S. b., \& Greyling, W. w. (2015). Dispelling the E-myths and preempting disappointment: Exploring incongruities between instructors' intentions and reality in asynchronous online discussions. South African Journal of Higher Education, 29(4), 50-76.

Curry, J. J., \& Cook, J. (2014). Facilitating online discussions at a manic pace: A new strategy for an old problem. Quarterly Review of Distance Education, 15(3), 1-12.

Delahunty, J., Jones, P., \& Verenikina, I. (2014). Movers and shapers: Teaching in online environments. Linguistics and Education, 2854-78. doi:10.1016/j.linged.2014.08.004

Frimming, R. E., \& Bordelon, T. D. (2016). Physical education students' perceptions of the effectiveness of their distance education courses. Physical Educator, 73(2), 340. doi:10.18666/TPE-2016-V73-I2-2759

Gillespie, G. L., Pritchard, T., Bankston, K., Burno, J., \& Glazer, G. (2016). An evaluation of forums for discussions on inclusion in a college of nursing. Nursing Outlook, doi:10.1016/j.outlook.2016.08.002

Jain, S., \& Jain, P. (2015). Designing interactive online nursing courses. Education, 136(2), 179. Retrieved from http://www.ingentaconnect.com/contentone/prin/ed/2015/00000136/00000002/art00008

Nielsen, A., Lasater, K., \& Stock, M. (2016). A framework to support preceptors' evaluation and development of new nurses' clinical judgment. Nurse Education in Practice, 1984-90. doi:10.1016/j.nepr.2016.03.012.

O'Brien, S. P., Marken, D., \& Petrey (2016). Student perceptions of scholarly writing. Open Journal of Occupational Therapy (OJOT), 4(3), 1-17. doi:10.15453/2168-6408.1253.

Oh, J., \& Steefel, L. (2016). Nursing students' preferences of strategies surrounding cinenurducation in a first-year child growth and development courses: A mixed methods study. Nurse Education Today, 36342-347. doi:10.1016/j.nedt.2015.08.019.

Phillippi, J. C., Schorn, M. N., \& Moore-Davis, T. (2015). Midwifery education in practice: The APGAR rubric for scoring online discussion boards. Nurse Education in Practice, 15239242. doi:10.1016/j.nepr.2014.11.002.

Schnetter, V. A., O'Neal, C., Lacy, D., Jones, M. M., Bakrim, K., \& Allen, P. E. (2014). Course development for web-based nursing education programs. Nurse Education in Practice, doi:10.1016/j.nepr.2014.06.007 
Shipman, D., Roa, M., Hooten, J., \& Wang, Z. J. (2012). Using the analytic rubric as an evaluation tool in nursing education: The positive and the negative. Nurse Education Today, 32246-249. doi:10.1016/j.nedt.2011.04.007

Smith, D. N. (2015). Effectively using discussion boards to engage students in introductory leadership courses. Journal of Leadership Education, 14(2), 229. doi:10.12806/V14/I2/AB3

Wright, T. L., Scherb, C. A., \& Forsyth, D. M. (2011). A rubric for evaluating online discussion contributions of graduate nursing students. Clinical Scholars Review, 4(1), 5-14. doi:10.1891/1939-2095.4.1.5

Wuttikietpaiboon, K. (2012). Engaging graduate students in rich asynchronous online discussions. Sam Houston State University. 
The Impact of Program-Wide Discussion Board Grading Rubrics on Students and Faculty Satisfaction 